Alaska State Office

222 West 7 th Avenue, \#13

Anchorage, Alaska 99513

\title{
Wildfires in Alaska in the 1980s
}

Compiled from Annual Fire Reports

of the Alaska Interagency Coordination Center

Andy Williams
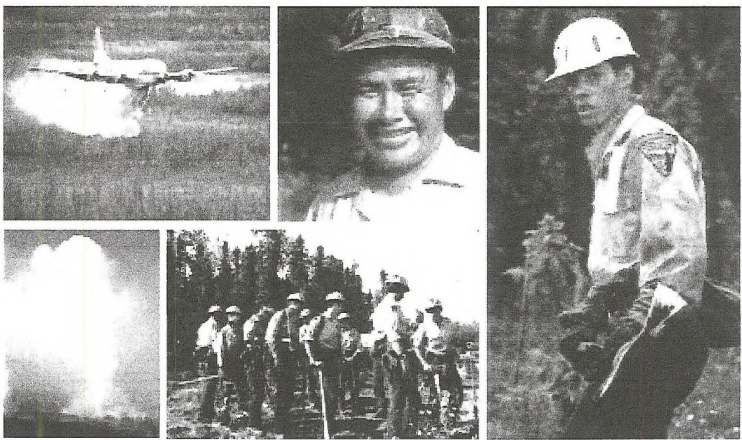



\section{The BLM Mission}

The Bureau of Land Management sustains the health, diversity and productivity of the public lands for the use and enjoyment of present and future generations.

\section{Editor}

Andy Williams is a public affairs specialist with the Alaska Fire Service.

\section{Open File Reports}

Open File Reports issued by the Bureau of Land Management-Alaska present the results of inventories or other investigations on a variety of scientific and technical subjects that are made available to the public outside the formal BLM-Alaska technical publication series. These reports can include preliminary or incomplete data and are not published and distributed in quantity.

The reports are available while supplies last from BLM External Affairs, 222 West 7 th Avenue \#13, Anchorage, Alaska 99513 and from the Juneau Minerals Information Center, 100 Savikko Road, Mayflower Island, Douglas, AK 99824, (907) 364-1553. Copies are also available for inspection at the Alaska Resource Library and Information Service (Anchorage), the USDI Resources Library in Washington, D. C., various libraries of the University of Alaska, the BLM National Business Center Library (Denver) and other selected locations.

A complete bibliography of all BL.M-Alaska scientific reports can be found on the Internet at: http://www.ak.blm.gov/affairs/sci_rpts.html. Related publications are also listed at http://juneau.ak.blm.gov. 



\title{
Wildfires in Alaska in the 1980s
}

\author{
Andy Williams
}

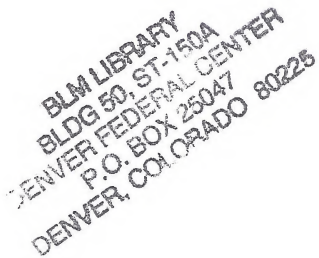

BLM-Alaska Open File Report 87

September 2003

U. S. Department of the Interior Bureau of Land Management 



\section{TABLE OF CONTENTS}

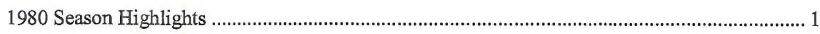

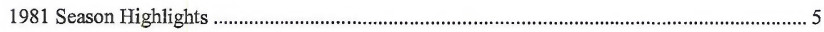

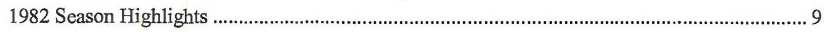

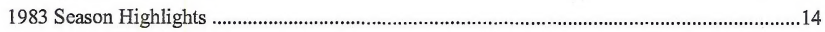

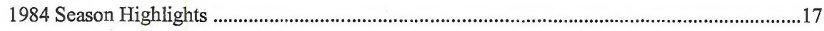

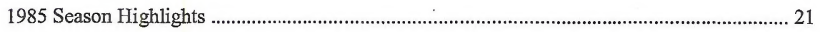

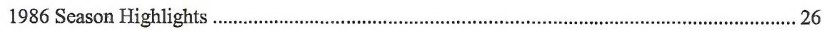

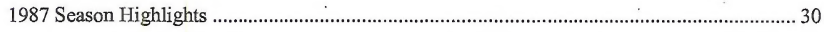

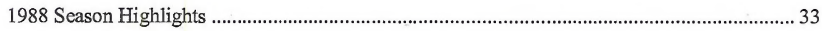

1989 Season Highlights ..................................................................................................... 36

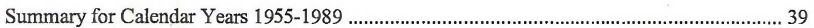





\section{Season Highlights}

The winter of 1979-80 was another in a series of mild winters that began in 1976. The evidence of the dry winter and an equally dry spring started showing up in early May. The State of Alaska battled a fire in the Delta Barley Project that started May 11. The Bureau of Land Management supported the State's effort but took no direct role on the fire. The fire ended up at 7,155 acres.

On May 5, smokejumpers attacked a persistent fire of unknown origin in a coal seam near Eagle. After two weeks of frustrating work, with very little rain, the decision was made to secure the perimeter and let the coal seam burn.

The dry spring produced the worst fire of the year when two fires on military lands south of Fairbanks combined and burned over 125,000 acres of military and state land. Although the fire burned from May 17 to mid-July, BLM's involvement ended in June. From May 17 to June 14, BLM provided advisers to the military and some on-line personnel. On June 14, BLM was given control of the fire. With a large commitment of equipment and personnel and the first substantial rains of the season, the BLM firefighters were able to contain the fire in five days. The fire was released back to the military, and the BLM provided an adviser for another 10 days.

Another military fire drew BLM forces in late May on the Yukon Training Site east of Eielson Air Force Base. The fire was in an active impact range and therefore an indirect attack was used. The fire was lined by bulldozers and left to burn out. The fire never threatened the dozer lines. The final size was 2,850 acres.

Even though the fire season started out dry, the atmosphere that prevailed over Alaska was generally stable, and the first lightning fire did not occur until June 15 . It was only a spot fire.

The only real lightning fire activity occurred from June 28 through June 30, when 19 lightning fires occurred. The fires were mostly in the Bettles and Eagle units. The peak day of lightning fires was June 30 with 10 fires, a far cry from 1979's peak day of 63 fires. The biggest fire in this three-day period was three acres.

The rest of the fire season proved to be relatively quiet. Only a few fires had any potential, but either rain hit them or large commitments of initial attack resources caught them before they could take off.

In summary, other than the early military fires, 1980 was a very inactive fire year in the Fairbanks District.

Alaska firefighters were involved in an international first in 1980. A Class I overhead team made up of eight Alaskans, five from the Fairbanks District, was sent to Ontario, Canada, to assist Canadian firefighters battling forest fires near Thunder Bay, Ontario. It was the first time an overhead team from the U.S. was used in Canada. 


\section{Statistics - Anchorage and Fairbanks Districts}

\begin{tabular}{|c|c|c|c|c|c|c|}
\hline \multirow[t]{2}{*}{ Cause } & \multicolumn{2}{|c|}{ Number of Fires } & \multirow[t]{2}{*}{ Total } & \multicolumn{2}{|c|}{ Acres } & \multirow[t]{2}{*}{ Total } \\
\hline & Anchorage & Fairbanks & & Anchorage & Fairbanks & \\
\hline Human & 19 & 56 & 75 & 132 & 128,074 & 128,206 \\
\hline Lightning & 18 & 66 & 84 & 1,459 & 227 & 1,686 \\
\hline False Alarms & & & 21 & & & \\
\hline Total & 37 & 122 & 180 & 1,591 & 128,301 & \\
\hline
\end{tabular}

\section{$\underline{\text { Retardant }}$}

Phoschek Tenogum/Fire/Trol

Gallons $\quad 287,800 \quad 19,100$

Assistance Dispatched to the Lower 48

Personnel: $30 \quad$ Aircraft: 4

Assistance Received from the Lower 48

Personnel:12

Aircraft

Fixed Wing Aircraft Used (Contract) 25

Fixed Wind Aircraft Used (Continuing Offer) 68

Total Fixed Wing Times (Contract \& Rental) $\quad 5,428.35$

Total Cost Fixed Wing (Contract \& Rental) \$2,829,336

Total Helicopter Times (Contract \& Renta1) $\quad 1,359.1$

Total Helicopter Cost

$\$ 1,142,720$

\section{EFF Pavroll}

Gross wages: \$507,631.71 No. hires: 436

\section{Facilities}

Upgrading of facilities continued at several field stations throughout the Fairbanks District in 1980.

In the Chena Area, most of the work took place at Bettles, Tanana and Fort Yukon.

At Bettles, the mess hall trailer was made fully operational. Solid walls and permanent roofs were added to the tent frames.

At Fort Yukon, a new heliport was built. The remodeling of the interior of the Dispatch Building was also completed.

At Tanana, the mess hall and wash trailer became operational. A dining area was built onto the mess hall. The warehouse was moved out of St. James Mission and put into a leased FAA 
warehouse.

In the Galena Area, a slow fire season allowed a great deal of facility work to be completed at Galena and Dahl Creek. At Galena, the last 40 feet of the new warehouse was completed. One of the upgraded tent frames was moved to the fenced security area behind the warehouse to be used as a hazardous materials storage area. A physical fitness trail was built next to the station.

The biggest project of the year at Galena was the acquisition and rehabilitation of two surplused Air Force barracks. One has been fully rehabed and will be ready for the start of the 1981 fire season. The other should be ready sometime during the 1981 season.

At Dahl Creek, siding work was completed on the buildings put up in the 1980 season.

There were no major facilities projects in the Fortymile Area in 1980.

\section{Special Projects}

I. Fire Weather - Fuel Conditions Project

The purpose of this project was to more accurately describe the characteristics of Alaskan fuel models in the National Fire Danger Rating System. The results of the study will help land managers better appraise the fire potential developing from weather patterns that occur during the fire season.

The project was conducted mainly out of Melozi Hot Springs northeast of Ruby. Other fuel samples were collected near McGrath. More data will be collected during the 1981 fire season to check and upgrade the 1980 data. The project is a cooperative effort between BLM and the U.S. Forest Service's Institute of Northern Forestry.

\section{Automatic Lightning Detection System}

The ALDS system was improved and added to in 1980. A graphic display terminal showed on a map where lightning was occurring and a graphics printer gave fire managers a hard copy map for out-of-office use and for historical files.

\section{Fire Weather Contract}

Due to budget constraints and duplication of efforts, the fire weather contract was dropped after the 1980 fire season. It was decided that because of improving ALDS capability and assistance from the National Weather Service, the contract service could be eliminated. 
Fairbanks District Fire Organization

1980

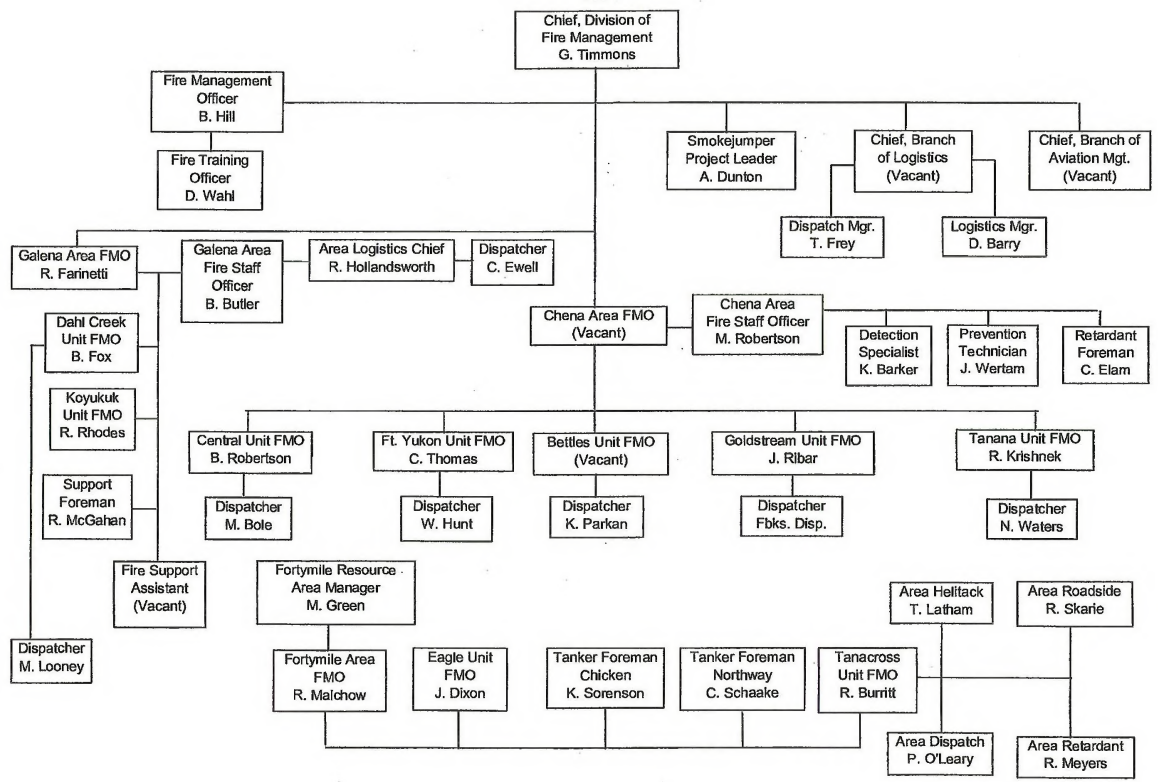




\section{Season Highlights}

The 1981 fire season began in mid-March when a white phosphorus flare from military exercises and a 70-mile-per-hour wind combined to cause a fire just south of Delta that grew to 10,500 acres in two days. The Bureau of Land Management sent several advisers to assist the Army in their suppression efforts.

By the first of May all areas of the Fairbanks District were reporting very dry fuel conditions. On May 18, lightning caused a fire in dry fuel conditions southwest of Nenana near Dune Lake. The fire spread quickly, and by the second afternoon, it was realized that a massive commitment would be necessary to stop the fire. The State of Alaska, as land owner, instructed the BLM to discontinue fire suppression activities, as they felt the values at risk were not commensurate with the high cost of suppression. BLM pulled off the fire, but within a week, the firefighters were back on the fire fighting on two flanks. One flank protected Doyon Ltd. land and the other flank protected Nenana Village Corporation land. With continued dry weather through June and a stubborn fire, BLM firefighters and equipment were on the Dune Lake fire for more than a month.

The first lightning bust of the year was on May 31 with 16 fire starts, mostly in the Galena Area. With a great deal of rain associated with the lightning and good use of jumpers and retardant, all the fires were held below 15 acres. All were out and demobed in a few days.

The busiest new fire start period of the season was between June 11 and June 22, when 82 lightning fires occurred, including several large project fires in the Galena and Chena Areas. The project fires required large commitments of people and equipment, and the Fairbanks District was soon depleted. The Anchorage District was also experiencing heavy fire activity and unable to offer much assistance. A request was sent to the Boise Interagency Fire Center, and the Fairbanks District received 117 smokejumpers, 82 overhead, six 20-person crews, 10 radio technicians, three retardant planes, and several plane loads of equipment.

The fires from June 11 to June 22 caused one Class 1 fire, two Class 2 fires, and eight Class 3 fires. The Class 1 fire was near Livengood and was managed by an Interior Department overhead team. The two Class 2 fires were near Hughes, where a Colorado overhead team was in charge; and southwest of Fort Yukon, where a Montana overhead team was used. The eight Class Three fires were split evenly with four in the Chena Area and four in the Galena Area.

The Fairbanks logistics center and warehouse were the main support point for these fires. Support was also given to the State of Alaska for a fire near Glennallen that had an Interior Department Class 1 overhead team. New fire starts compounded the problem of supporting ongoing fires by diverting people and equipment to initial attack fires. By the end of June, all support systems in the Fairbanks District were working at maximum capacity and the fires still had the upper hand.

The weather systems through early and mid June wandered back and forth across the Interior, causing extensive convective activity, but leaving only small amounts of rain. Finally, on June 26, a strong low-pressure system was spotted near Wrangell Island north of Siberia. It was the first of a series of cool, wet lows to move through the Interior, and signaled the end of what had looked like a record fire year. From June 23 through the end of September, only 128 acres of land burned due to new fires.

One big highlight of the season remained after the project fires were unstaffed. It was a request 
by Canada for emergency firefighter crews for a fire near High Level, Alberta. The Fairbanks District send 18 EFF crews, a smokejumper hand crew, and 11 overhead to the Canadian fire. The Anchorage District sent nine EFF crews and four overhead. Large amounts of equipment and supplies were also sent to support the crews at the fire. They stayed on the 255,000 -acre fire six weeks.

The cool, wet weather of July and August allowed the Fairbanks District to send assistance to the Lower 48 . Seventy-two smokejumpers, 48 firefighters, one cook, one overhead, one warehouser and one Volpar airplane went south to help.

\section{Statistics - Anchorage and Fairbanks Districts}

\begin{tabular}{|c|c|c|c|c|c|c|}
\hline$\underline{\text { Cause }}$ & \multicolumn{2}{|c|}{ Number of Fires } & Total & \multicolumn{2}{|l|}{ Acres } & Total \\
\hline & Anchorage & Fairbanks & & Anchorag & Fairbanks & \\
\hline Human & 32 & 47 & 79 & 563 & 2,559 & 3,122 \\
\hline Lightning & 71 & 138 & 209 & 191,233 & 341,859 & 533,092 \\
\hline False Alarms & & & 34 & & & \\
\hline Total & 103 & 185 & 322 & 191,796 & 344,418 & 536,214 \\
\hline
\end{tabular}

\section{$\underline{\text { Aircraft }}$}

$\begin{array}{lccc} & \text { Contract } & \text { Continuing Offer } & \text { Total } \\ \text { Fixed Wing } & 26 & 86 & 112 \\ \text { Helicopters } & 5 & 25 & 30\end{array}$

\begin{tabular}{llll}
\multicolumn{2}{c}{ Passengers Hauled } & \multicolumn{1}{c}{ Pounds Hauled Hours Flown } \\
Fixed wing & 10,538 & $3,445,819$ & 5,549 \\
Helicopters & 20,551 & $1,733,438$ & 2,078
\end{tabular}

Retardant

Fairbanks District: 665,400 gal.

Emergency Firefighter Payroll

Gross wages: $\$ 2,137,861.28$ No. hires: 1,448

Assistance Dispatched to Lower 48

Personnel: 123 Aircraft: 1

Assistance Received from the Lower 48

Personnel: 330 Aircraft: 4

Paracargo

438,540 lbs. 


\section{Facilities}

The 1981 fire season was extremely busy for the Fairbanks District's food service organization at the Division of Fire Management. Food Service began on April 6 and ran through Sept. 11. Food Services was provided not only at Fort Wainwright, but also extended from Tanacross to Kiana and as far north as Galbraith Lake

Duties of the food service operation extended beyond providing for support of fire camps. They included the Central Arctic Management Area project at Galbraith Lake and a Cadastral Survey camp at Fort Yukon.

Food was provided at Galbraith Lake from June 21 through Aug. 15. Services included food, kitchen, cooks and food service workers. Food service personnel were able to obtain experience in a small kitchen, of the type maintained at fire outstations, and personnel in the field were provided hot meals at the end of the day. A kitchen for the Cadastral Survey was in operation from Aug. 21 through Sept. 25.

Food Services opened what is believed to be the first field kitchen at a staging area at the Dune Lake fire near Nenana. An important advantage of maintaining the kitchen was the availability of hot meals on an as-needed basis.

An additional advantage to maintaining the field kitchen was the low cost of providing the meals. Meals, on the average, were provided at the cost of $\$ 2.08$ per meal.

During the peak of the fire season, the Fairbanks kitchen served a one-day total of 967 hot meals and 160 box lunches. The Fairbanks kitchen served a season total of 42,054 meals, and Galena provided a season total of 12,982 meals. 


\section{1}

Falrhanks District

Dlulsion of Fire Management

Organlzation Chart
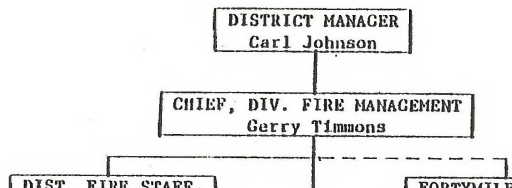

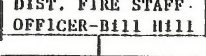

FIRE TRAINING OFE. Don Halı1
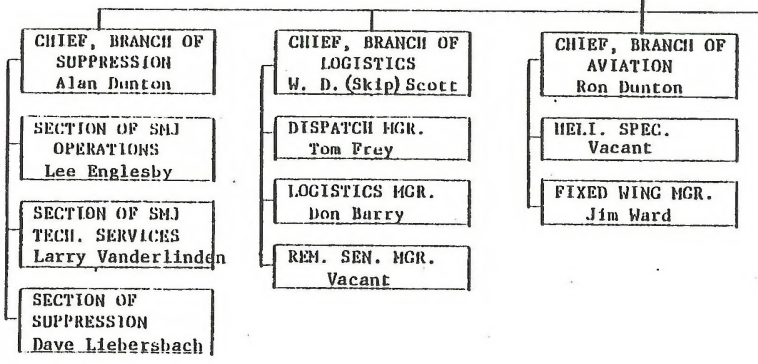

FORTYMILE AREA

MGR.-Mike Green

FORTYMILE FMO

- Dick Malchow

$\bullet$

(2)

]

Bob Burritt 


\section{Season Highlights}

-The 1982 fire season was the first year for the newly organized Alaska Fire Service. The Alaska Fire Service is the only Department of the Interior fire suppression organization in Alaska: AFS is responsible for providing fire suppression and related support services on Bureau of Land Management, Fish and Wildlife Service, National Park Service, Bureau of Indian Affairs and Alaska Native corporate lands on a statewide basis in Alaska. The State of Alaska assumed protection responsibility for state and private lands.

The 1982 fire season got off to a late start due to spring breakup being three to four weeks later than usual. The late spring retarded the drying process considerably. An above-average amount of moisture remained in the fuels throughout the season. This high fuel moisture seemed to keep fires from spreading and made suppression efforts easier.

June 17 saw the first day of multiple fire occurrence. The fire bust lasted from June 17 to July 14. During the period, 118 fires were reported. July 8 was the day with the highest fire occurrence -45 fires started that day. Of 118 fires reported, only 10 fires grew to 100 acres or larger. The fire occurrences during this time were statewide - from the Canadian Border to the Seward Peninsula in the west.

The only project fire of the season was the Kennebec fire, located on Fish and Wildlife Service land 30 miles south of Northway. The fire reached a size of 31,430 acres. A Class 1 overhead team was placed on the fire.

The Alaska Fire Service sent a Class 2 overhead team plus two hotshot crews and four emergency firefighter crews to the Yukon Territory, Canada, to a fire that was eight miles out of Watson Lake and threatening the community. AFS seasonals were also sent from Watson Lake to Stewarts Crossing, Y.T. Good use of burnout and backfiring allowed them to save that community.

The Alaska Smokejumpers had a significant event in 1982. For the first time they made a fire jump with the newly developed ram-air parachute. A total of nine fires were jumped with the new parachutes.

During the 1982 season, 44 firefighters from the Boise Interagency Fire Center and other states were sent to Alaska on a six-week detail. During the fire bust an additional 66 personnel were brought to Alaska.

After July 17 only 42 new fires were started, the largest being only 18 acres, as the 1982 fire season came to a close. 


\section{Statistics - AFS}

\begin{tabular}{lcr} 
& Number of Fires & Acres \\
\cline { 2 - 3 } Human & 60 & 599 \\
Lightning & 189 & 70,199 \\
False alarms & 34 & \\
Total & 283 & $\mathbf{7 0 , 7 9 8}$
\end{tabular}

$\underline{\text { Aircraft }}$

Fixed Wing

Contract Continuing Offer Total

Helicopters

34

126

160

10

26

36

Fixed Wing

Passengers Hauled

Pounds Hauled

Hours Flown

Helicopters

Total

4,361

$2,021,289$

6,025

2,401

8,426

Retardant

171,875 gal.

Emergency Firefighter Payroll

Gross Wages: $\$ 1,230,351.09$ No. Hires: 1,075

\section{Paracargo}

$129,078 \mathrm{lbs}$.

\section{Assistance Dispatched to Lower 48 and Canada}

Personnel: 123

Assistance Received from Lower 48

Personnel: 242 Aircraft: 2

\section{Special Projects}

The 1982 fire season was the first season for the Tanana-Minchumina Plan. The TananaMinchumina Fire Plan applies to approximately 31 million acres of federal, state and Native corporation and other private lands in central Interior Alaska. The Fortymile Fire Management Plan refers to an area of approximately 14 million acres located in the eastern part of the fireprone Interior region of Alaska. The plans contain four fire management alternatives or options that range from immediate and aggressive suppression to no initial attack. Implementation of the plans allows for the use of cost-effective strategies to reduce fire suppression expenditures, and to 
assure responsiveness to the land manager's and land owner's objectives.

The purpose of the Tanana-Minchumina and Fortymile plans is to provide an opportunity for land managers within the planning area to accomplish their land-use objectives through cooperative fire management.

The objectives of the fire management plans are to ensure coordination and consolidation of suppression efforts, and to provide suppression options which help realize current resource management objectives in a manner that maximizes the effectiveness of each dollar spent.

The Alaska Fire Management Plans are not a land use plan. Rather, they are a guide to coordinate the use of fire suppression forces among a wide variety of land managers and to promote a comprehensive fire management program. They do not develop land use objectives: they implement these objectives relative to fire management.

\section{Initial Attack Management System (IAMS)}

The IAMS project is to eventually provide fire management with a fuels data base from Landstat imagery and digital terrain information. This is useful in making decisions for initial attack decisions. The fuels map is to be integrated with the Alaska Lightning Detection System (ALDS) and Remote Automated Weather Stations (RAWS) to form the data base.

At the present time, the IAMS project is in a presentation state. This means that the project is showing management what can be accomplished. The computer used for the project was the Tektronix 4051. This system was slow and there were problems with the fuels maps. Consequently this system was not used to its fullest potential this season.

\section{Fire Behavior/Meteorology}

The Alaska Black Spruce Program was run again during the 1982 fire season from June 1 to Sept. 6 by the fire behavior analyst, the fire weather forecaster from the National Weather Service, and three BLM meteorology technicians. Daily fire weather forecasts were provided for 30 sitespecific locations throughout Interior Alaska and the Kenai Peninsula.

Fire behavior calculations were formulated from the predicted weather conditions. The calculations determined a fire danger level of low, medium, high or extreme to be expected for the areas surrounding each of the 30 weather reporting sites. This information was then sent to the BLM stations for planning the day's fire strategies.

The Black Spruce Program's fire behavior calculations and fire danger levels were used as the basis for the revised AFS staffing guidelines. Daily fire danger levels determine the necessary manpower force needed for each zone to handle the expected fire load.

\section{Facilities}

The newly organized Alaska Fire Service moved into its new headquarters in Building 1555, across the street from its old site in the BLM Fairbanks District Office.

The Branch of Fire Coordination added a situations office to its organization. The situations office acts as a gathering and dissemination point for fire intelligence. It provides a daily fire situation briefing for fire management overhead and client agency land managers. It also makes available detailed information and maps for specific fires. 
Circle Hot Springs and Tanana Zones both had their headquarters in the AFS building this season. Zone activities for these two zones were planned and implemented at Fort Wainwright through the zone support organization and the Fire Coordination Center.

Station improvements in the Tanana Zone included plumbing and station maintenance and repair at Minchumina and improvements to the station grounds and heliport. Tanana Station installed 500-gallon aviation gas and jet fuel tanks and electric fuel pumps at the fueling site. Bettles upgraded the fuel site and performed maintenance upgrades on the station buildings and put a new well into service.

The 1982 fire season in McGrath was one of transition from a district fire organization with major support and command functions in Anchorage to operation as one of four statewide zones reporting to headquarters in Fairbanks. The transition went smoothly. 
Alaska Fire Service

1982

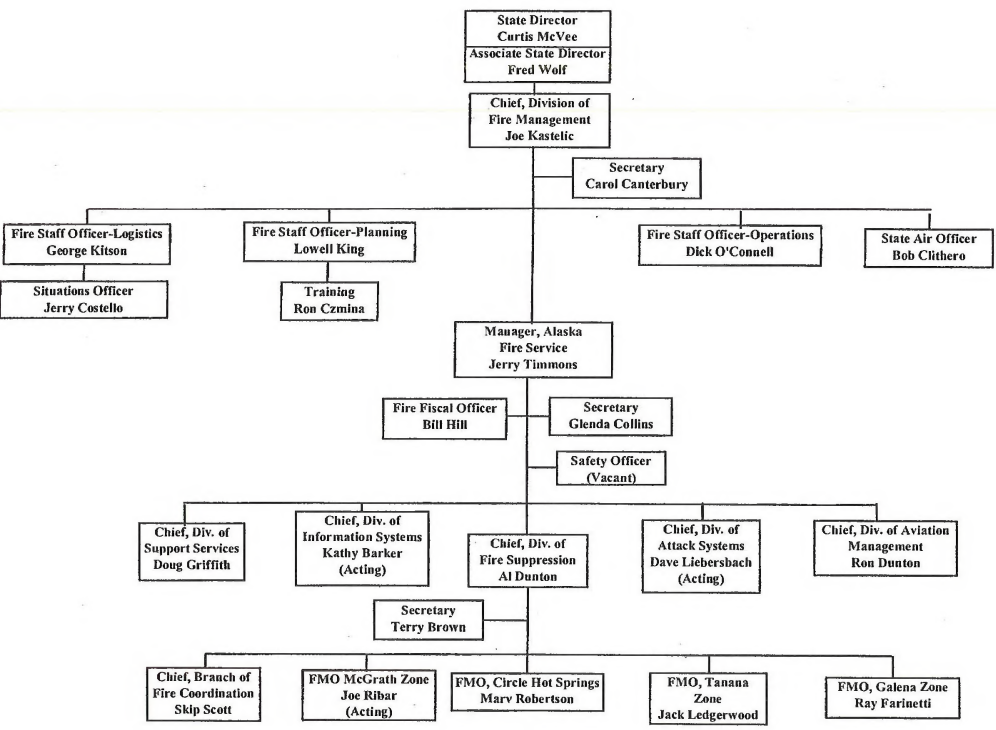




\section{Season Highlights}

The 1983 season for the Alaska Fire Service began in late April with a 200-acre military fire on Fort Greely. During May military fires burned 35,800 acres, while other areas remained quiet. By late May extremely dry conditions existed across Interior Alaska due to an early spring breakup and very low accumulations of rainfall. These dry conditions made for extreme fire dangers and initial attack of fires was much more difficult. The dry conditions continued until August.

Although only 98,164 acres were reported burned, the season held some memorable fires. The first multiple fire occurrence days began on May 29 and lasted until June 2. Thirty-eight fires started during that period.

The Rosie Creek fire started on May 29 just southwest of Fairbanks. At first the human-caused fire appeared to be spreading to the northeast, toward some housing developments, but the winds shifted to the southeast, pushing the fire through an unpopulated area toward the Parks Highway, which made an effective fire line. AFS fielded a Class 1 overhead team and equipment support to the State's fire.

The major fire bust of the year was between June 19 and July 25, when 365 fires started. June 27 had the highest number of starts when 47 fires started, while 58 fires were burning. Seventy fires started on July 7 and 8, with 46 fires burning. Fire \#8596, located near Minto, was the major project fire for AFS. It burned 28,000 acres and a Class 1 team was placed on it. Two Class 2 overhead teams fielded by the State were used on other AFS fires during the bust.

Fire occurrence dropped to almost nothing during August as the weather turned rainy across the Interior for the entire month.

The 1983 season was a good season for the implementation of interagency coordination. From preseason training and throughout the fire season, AFS made a major effort to train and utilize personnel from other agencies.

1983 marked the end of Gerald Timmon's 20 years in Alaska fire management. He was the first manager of the Alaska Fire Service, a term characterized by his thoughtful consideration for firefighters and dedication to excellence. 
1983 Statistics - AFS

\begin{tabular}{lccc} 
& Number of Fires & & Acres \\
\cline { 2 - 3 } Human & 68 & & 64,336 \\
Lightning & 336 & 33,798 \\
Total & 451 & 98,164
\end{tabular}

Assistance Received from Lower 48

Personnel: 456 Aircraft: 4

Aircraft

Helicopters

10,758

$1,833,805$

2596.5

Fixed Wing

11,083

$2,805,438$

5403.8

Retardant

992,450 gal.

Paracargo

$162,000 \mathrm{lbs}$.

EFF Pavroll

Gross Wages: \$1,969,374.70 No. Hires: 330 
Alaska Fire Service

1983

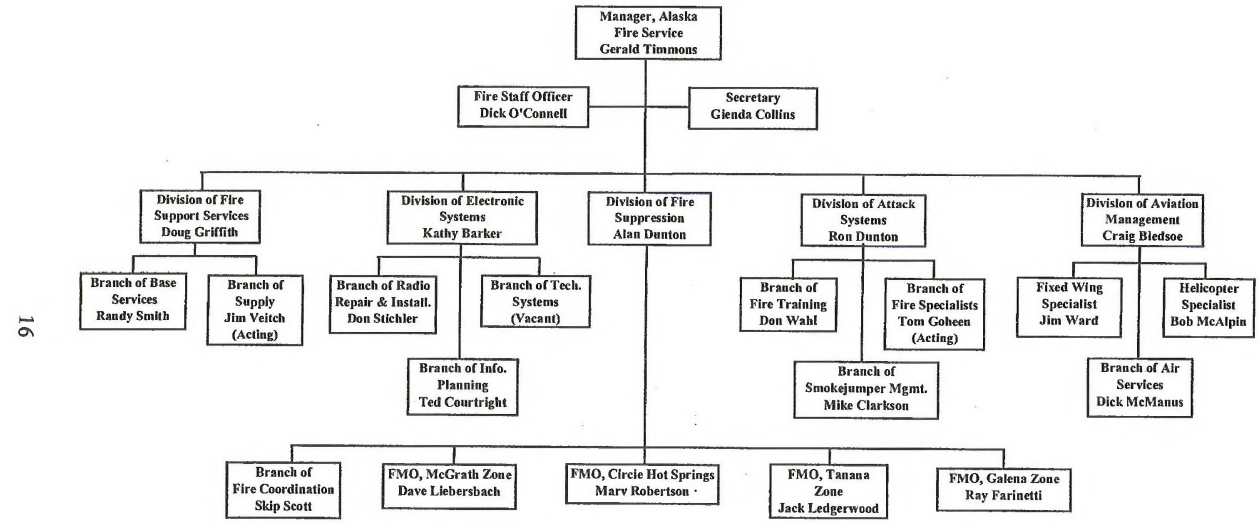




\section{Season Highlights}

A late breakup and a cool May kept fire activity down for the Alaska Fire Service. Most of May's fire activity for AFS involved assisting the State of Alaska with their fire problems in Southcentral Alaska.

The first sustained fire activity of the season began on June 4 and continued through June 10. June 6 was the most active day with 15 fire numbers issued.

From July 5 to the end of the month only 16 more fire numbers were issued. This was due to a shift of weather patterns, which brought continued moisture to all of the Interior of Alaska. The month of August was even slower with only four fire numbers issued and four acres burned.

Five new fire management plans went into effect in June 1984. They were the Yukon-Togiak, Kenai, Upper Yukon-Tanana, Seward-Koyukuk, and the Kobuk Fire Plans. More than 40 percent of the lands in these plans were placed in limited response fire management areas. This limited acreage combined with the acreage already in the limited option category in other plans amounted to very large areas where no initial fire suppression action was taken. Because of the large acreage in the limited category, fire managers were able to concentrate their initial attack forces on fire management option areas with higher priorities. This definitely helped the initial attack success rate.

The 1984 fire season had more fire numbers issued than the 1983 season, and burned 34,000 acres more than in 1983. 93,000 acres of the total acreage burned in 1984 was in the limited response areas with the two largest fires of the season, the Wapoo Fire at 37,570 acres and the Mud Fire at 12,000 acres in limited areas.

\section{Fire Statistics - AFS}

\begin{tabular}{lrrr} 
& Number of Fires & & Acres \\
\cline { 2 - 3 } Human & 53 & 3,348 \\
Lightning & 356 & 112,523 \\
False alarms & 46 & \\
Total & 455 & $\mathbf{1 1 5 , 8 7 1}$
\end{tabular}

\section{Paracargo}

$101,130 \mathrm{lbs}$.

\section{EFF Payroll}

Gross Wages: $\$ 507,004 \quad$ No. Hires: 798

\section{$\underline{\text { Aircraft }}$}

Passengers Hauled

Cargo Hauled

Hours Flown

$\begin{array}{cc}\text { Helicopters } & \text { Fixed Wing } \\ 5,691 & 7,594 \\ 664,665 \text { lbs. } & 1,075,863 \text { lbs. } \\ 1,870 & 5,928\end{array}$




\section{Canadian Fire Weather Index}

The Canadian Fire Weather Index (CFWI) is the national program used in Canada to measure daily fire danger levels as the National Fire Danger Rating System (NFDRS) is the program used in the United States. The NFDRS outputs have proved to be unreliable for use in Alaska but the CFWI Duff Moisture Content (DMC) Portion has proven to be a very reliable indicator for longterm drying of the duff layers and mirrors the actual number of fire starts that occur on a daily basis. The CFWI has been run for the past several years for seven stations where 24-hour yearround weather data is available. The seven stations are Fairbanks, Galena, Fort Yukon, McGrath, Bettles, Tanana and Northway.

The Canadian Fire Weather Index again proved to be a good indicator of the potential fire danger and a reliable guide of drought or long-term drying conditions. The curves plotted for each of the seven stations followed the multiple fire occurrence trend reported in 1984 and also the overall fire behavior observed in the field.

\section{Special Projects}

The Merlin (199Z) U.S. Forest Service infra-red aircraft out of the Boise Interagency Fire Center was used in Alaska for six days (6/28-7/4) during the 1984 fire season. The Merlin proved to be useful in monitoring Limited fires and taking infra-red photos of these fires.

The $\mathbb{R}$ product varied from fire to fire with weather being the main influencing factor. Infrared can take photos through smoke but not through clouds or rain.

\section{Uses of the Merlin Infra-red equipment}

1. Detecting fire perimeters of large fires under smokey conditions is one of the best uses of this equipment. The IR equipment can see through smoke and can map the perimeter of active fires and pick up spot fires out ahead of the main fire perimeter.

2. The IR equipment can be used during normal night-time hours or darker hours in Alaska during August. In the Lower 48, most of the $\mathbb{R}$ flights are at night, when photos produced are most timely for the day shift on project fires.

3. Under multiple fire conditions with smokey flying conditions, the Merlin can be used to detect new fire starts and monitor carryover fires that can not be flown by other aircraft. The Merlin can fly at 40,000 feet and cruises at 240 knots, making it possible to cover a large part of the state and take IR photos of numerous fires during the eight-hour daily flight time.

\section{$\underline{\text { Limitations }}$}

1. Infra-red could not take photos through clouds or rain, or when the cloud cover was below 4,000 feet. If rain droplets get on the IR mirrors and the image is washed out, the aircraft is forced to land and clean the mirrors. The afternoon thunderstorms with associated clouds and rain shower forced all IR missions to be flown from 2200 to 1000 the next day to avoid these cloudy and rainy conditions. 
2. The equipment is not adequate for use on fires in the final stages of mopup or for declaring fires out. The Probeye is the best available IR equipment to use in these situations.

3. The IR equipment could not delineate burned areas on all fires, especially during the morning hours when an IR map would be most helpful. This is probably because of the lack of a marked temperature gradient between burned and unburned vegetation. Night-time cooling and relative humidity recovery of both burned and unburned vegetation caused all vegetation to look the same on the IR photos with very few hot spots showing up. The IR crew said it was the first time they have encountered this problem. It is a major limitation because there is not enough time to hand sketch fire perimeter maps on so many fires flown. If a perimeter map is needed, the fire has to be a going, active fire hotter than 600 degrees centigrade or the flight has to be scheduled during the hottest part of the day.

4. Many areas of the state do not have inch-to-the-mile maps. The IR crew is used to numerous sizes of complete maps. The lack of detailed maps in Alaska was frustrating to them and did not allow for map sketches of most of the fires that were flown.

5. The pilots do not like to land the aircraft on gravel or dirt runways. The aircraft has reversible props, which tend to pick up a lot of rocks, which can damage the props seriously enough to require maintenance.

\section{Station Improvements}

Tanana Zone. Tanana Station had major work going on as a result of the zone headquarters moving out of Fairbanks and to the field. This included the moving of eight trailers, three of which were installed with electricity and power. A fuel tank was buried to supply the trailers with fuel for the heaters. A new water treatment system was installed. The messhall received a new 16 $x$ 46 " eating and service area.

McGrath Zone. McGrath station construction and remodeling was kept to a minimum this year due to the transfer of responsibilities from AFS to the State of Alaska for the 1985 fire season. Remodeling of the old log warehouse was competed this year and has turned into administration offices. The McGrath station will be leased to the State beginning in 1985, along with the retardant and fueling sites.

Galena Zone. The new dispatch addition to the Galena zone office neared completion. The retardant site was completely modernized in 1984 . It was made into a permanent site with the addition of two 25,000 gallon tanks and new dispensing and mixing hardware. A pad for the backhaul building was laid with the building to be erected in the spring of 1985 . 


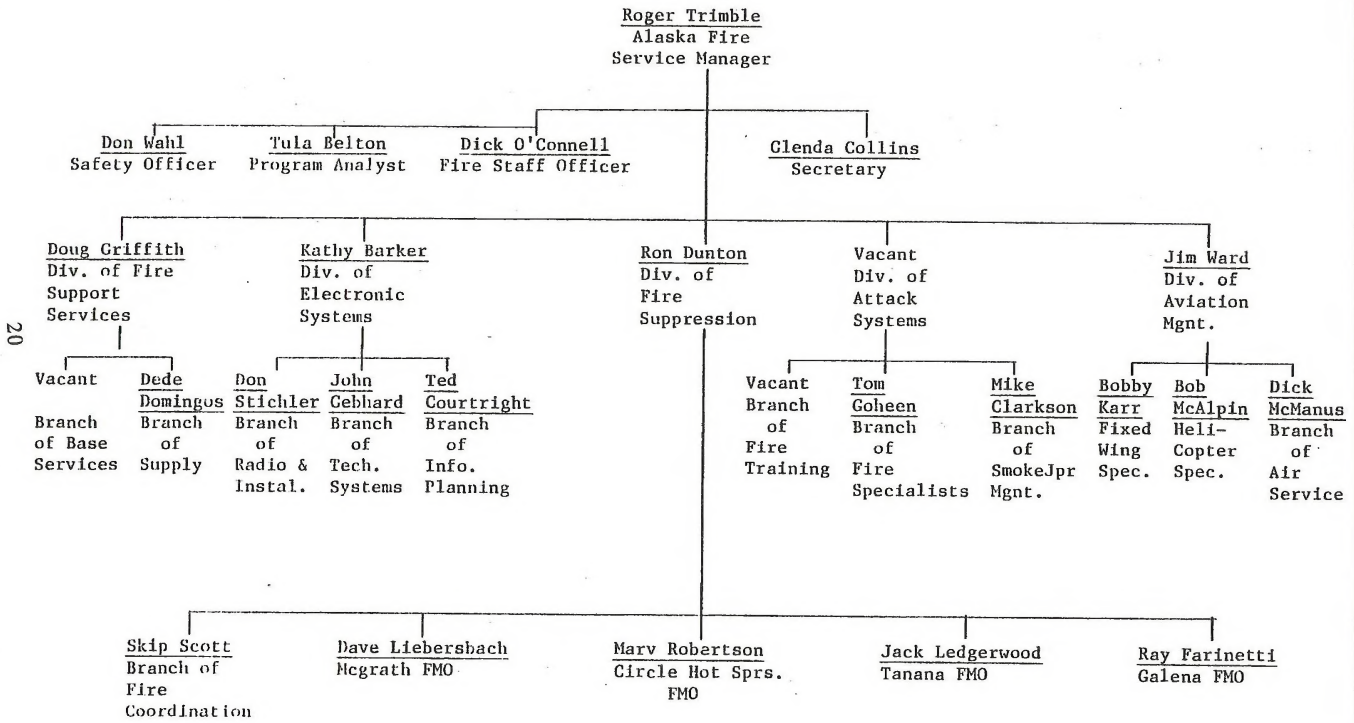




\section{Season Highlights}

The 1985 fire season was a slow starter and a fast finisher. A great deal of the season's activity and work load was centered around supporting fires in the Lower 48.

Most of the Alaska Fire Service McGrath Fire Management Zone was taken over by the State of Alaska in 1985. The state leased the same BLM administrative site that had been used by AFS. Those areas of the old McGrath Zone not taken over by the State were added to the Galena Fire Management Zone. The addition did cause some problems for the Galena Zone because of the increased distances to cover with detection, fire monitoring and logistical support of Fires. Galena worked with State personnel in McGrath to alleviate some of those problems by coordinating the monitoring, detection and suppression efforts of fires in the area.

The North Slope Fire Plan went into effect during the early part of the season. All lands within AFS protection except the Venetie Reservation and Fort Wainwright military land are now covered by Fire Management Plans.

The combination of a heavier than normal snow pack and a cool spring kept fire activity through most of May to a minimum. Only northeastern Alaska had a below normal snowpack and was dry enough by late May to cause some concern among fire managers. A human-caused fire on May 24, east of Fort Yukon, appeared at first to be a typical spring fire in the Yukon Flats that would be suppressed with minimum difficulty. The dryness of the fuels coupled with active fire behavior forced a large commitment of resources and personnel. The fire was controlled at 659 acres and declared out on June 4.

June's fire activity was low with only 45 fire numbers issued. The fires were a mixture of both human-caused and lightning-caused. The human-caused problem was associated with the dryer northeastern area around Fort Yukon.

July started out as slow as June had left off. Several days in early July had new lightning fire starts but the fires remained small because the thunderstorms that spawned them were usually wet.

The Alaska fire season was starting to shape up as one of the slowest on record while the Lower 48 was experiencing one of its busiest seasons on records. When all the resources in the Lower 48 had become exhausted, AFS was asked what it could provide. During the month of July, while AFS fire activity waned, logistical activity was constant in the AFS Fire Coordination Center supporting the Lower 48 requests. Coordinating closely with other Department of Interior agencies, the U.S. Forest Service and the State of Alaska to fill numerous orders received from the Boise Interagency Fire Center, AFS sent 41 crews and several hundred regular firefighters and overhead to the large fires in the western United States. In addition to the personnel sent were air tankers, helicopters, lead planes and thousands of pounds of supplies, equipment and dry retardant. On one day alone, five U.S. Air Force C-141 transport planes moved 285,000 pounds of supplies to fires in California. The year 1985 marked the largest support effort ever by Alaska to the Lower 48.

Weather over northern Alaska by mid-July had begun to improve and fuels were beginning to dry out. Manpower and equipment from the Lower 48 had begun to trickle back to Alaska as the fire activity in the Western United States subsided.

The end of July saw the beginning of what turned out to be a late season fire bust. Between July 28 and August 10, 161 fire numbers were issued out of the total of 261 fire numbers for the 
year. Personnel and equipment were now being ordered back from the Lower 48 to support fires in Alaska.

Several limited fires in Northeastern Alaska which had started in mid-July were now threatening Native allotments, compounding the problem of the late fire bust. On Aug. 6, a Class 2 team was committed to a fire east of Chalkyitsik. By Aug. 8 the fire posed a major suppression problem and a Class 1 team was assigned. Also on Aug. 6, a fire was detected southeast of Birch Creek that exhibited extreme fire behavior and grew to 25,000 acres in 24 hours. A Class 1 team was committed on Aug. 8 to set up fire breaks around the village of Birch Creek. A fire south of Bettles that seemed to have the potential to grow like the Birch Creek fire was hit with a heavy commitment of air tankers, Category 1 crews and a Class 2 overhead team. By Aug. 10, cooler, moisture-laden weather had moved across the state and shut off the lightning for the rest of the year. From that point on, the job was to secure lines, mop up and demob. The Alaska fire season was over for another year.

AFS did assist the Lower 48 one more time. On Aug. 29 the Alaska Class 1 Interagency Fire Team was ordered to a 30,000-acre fire near Omak, Wash. AFS sent a full Class 1 long team consisting of 23 AFS and BLM, State of Alaska and U.S. Forest Service personnel, who worked the fire for 10 days before returning to Alaska.

Some people have referred to 1985 as the year of two fire seasons, one in the Lower 48 and the late one in Alaska. It was also a season of improved interagency cooperation, where agencies worked side by side in Fairbanks to support each other's fire problems as well as those in the Lower 48 . 


\section{Fire Statistics - AFS}

\begin{tabular}{lrr} 
& Number of Fires & Acres \\
\cline { 2 - 3 } Human & 54 & 1,238 \\
Lightning & 165 & 370,992 \\
False Alarms & 38 & \\
Support & 4 & \\
Total & 261 & 372,230
\end{tabular}

\section{EFF Pavroll}

Gross Pay: $\$ 2,723,299$ No. Hires: 1,190

\section{Retardant}

176,500 gal.

\section{Aircraft}

Passengers Hauled

$\begin{array}{cc}\text { Helicopters } & \text { Fixed Win } \\ 8,515 & 8,587 \\ 571,800 & 732,856 \\ 5,656 & 5,977\end{array}$

Cargo Hauled

Hours Flown

5,656

Paracargo

$469.000 \mathrm{lbs}$.

Assistance Dispatched to Lower 48

Personnel: 1,072 Aircraft: 19

Assistance Received from Lower 48

Personnel: 395 Aircraft: 11

\section{AFS Hotshot Program}

This year, the two AFS Hotshot Crews became fully operational as Category 1 crews. The AFS Hotshot mission now includes work in Alaska, as well as availability as a national fire suppression resource.

The early part of the 1985 fire season was spent in training, project work, State of Alaska fires and numerous fires in the Fort Yukon area. July saw both crews dispatched to fires in the state of Idaho. The crew performance and resulting fire evaluations from these fires reinforce the viability of the AFS Hotshots as a national resource. The Hotshot season ended in mid-August, with the last fires part of the Fort Yukon complex. 


\section{Fire Training}

1985 was the year chosen for changing fire management systems from the Large Fire Organization to the Incident Command System. Along with this change came transition training and involvement with transition and qualifications, certifications and the computer system that tracks them. Other major projects included: continued development of an Alaska oriented crew training package, major revision of the Alaska Handy Dandy and a management system to better direct training for improved efficiency, in addition to the regular training schedule and numerous fire assignments. 
ALASKA FIRE SERVICE 1985

ROGER TRIMBLE

ALASKA FIRE SERVICE MANAGER

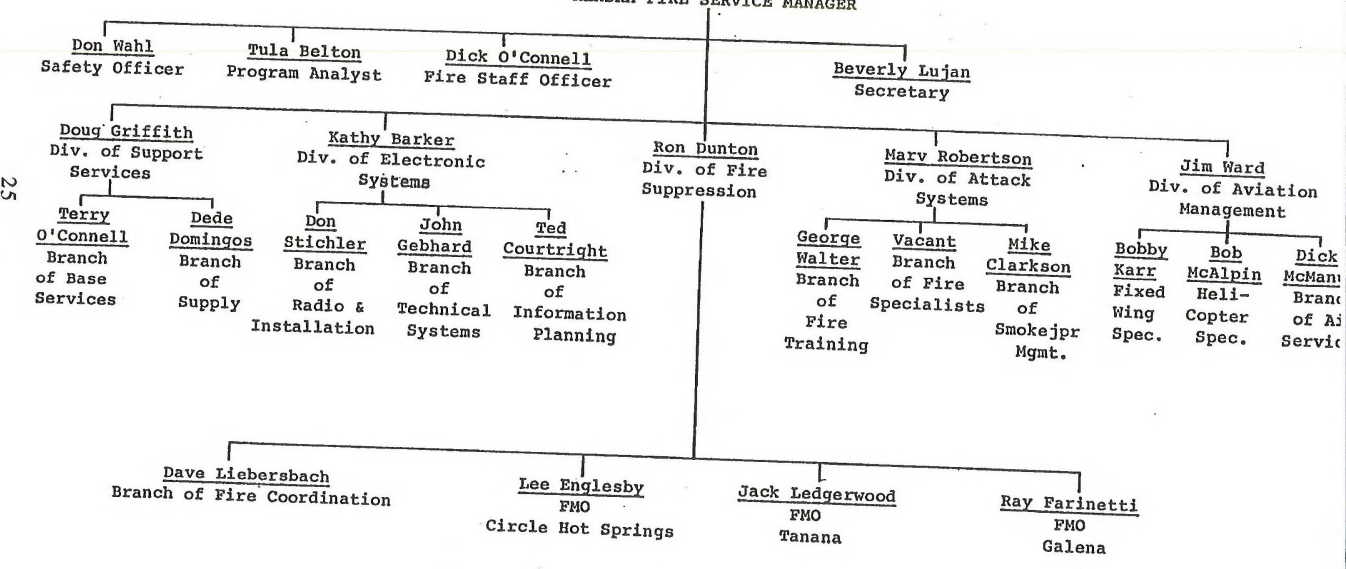




\section{Season Highlights}

The 1986 fire season brought with it some significant changes in the Alaska Fire Service as well as some unusual fire activity. Roger Trimble, the Manager of the Fire Service, departed for Washington, D.C., to become the Bureau's Chief of Fire and Aviation. He was replaced in Alaska by Tom Owen, former District Manager of the Carson City District in Nevada, on July 14. In addition, the BLM'S State Aviation Officer was moved into the AFS organization.

The fire season started normally in 1986, with fire activity beginning in April in the Anchorage/MatSu and Fairbanks areas and increasing throughout May.

The snow pack in Alaska was far below normal. Combined with a cool, dry spring and late greenup, these unusual drought conditions caused 1-hour fuels to drop down to 10 percent or lower in more than 20 weather stations around the state in June.

In mid June, the activity level picked up significantly. Lightning activity was at record heights in the northeastern part of the state, averaging more than 2,000 lightning strikes a day for 10 days in a row. The result was nearly 240 fires and 142,560 acres burned. Ten project-size fires were staffed simultaneously. This had a severe impact on the agencies within Alaska, and also on the Boise Interagency Fire Center, which provided support in overhead personnel, communications equipment, retardant and supplies and infrared aircraft.

These extreme burning conditions prevailed throughout June and early July. The conditions prompted management to provide fire shelters to all persons working on active fire lines. Smokejumpers on initial attack were deployed 16 to a fire in an attempt to contain the fires at 10 acres or less. A large land area in the Interior labeled in modified protection was changed to limited protection level because of the critical shortage of initial attack resources.

By the height of the fire season there were 83 emergency firefighter crews in the field at one time. They consisted of both crews on the organized rotation list and crews that were not. Of the 73 crews on the list, only four were not used because of their unavailability at the time of call-out.

Moisture started moving into the state around mid July and by the end of the month, new fire starts were virtually non-existent throughout the northern Interior. By this time there had been more than 660 fires that burned more than 480,000 acres statewide.

As fire activity slowed in Alaska, it began to increase in the western part of the Lower 48 . Alaska reciprocated for the earlier aid by sending EFF crews, overhead personnel, smokejumpers, aircraft, equipment and supplies.

The heavy rains of July and August didn't reach the Tok area, which remained in drought conditions well into September. Twenty fires occurred in September from hunters and tourists. None of the fires resulted in significant acreage, but the activity was far above normal for that time of year.

With the coming of October, so came an end to what was the most active fire season since 1974. Without the cooperative efforts of the agencies throughout Alaska and the Lower 48 , this intense fire season would have been much worse. 
1986 Fire Statistics - Statewide

\begin{tabular}{lrrrrrr} 
Cause & \multicolumn{2}{c}{ Number of Fires } & Total & \multicolumn{2}{c}{ Acres } & Total \\
\cline { 2 - 5 } & AFS & State & & AFS & State & \\
Human & 22 & 383 & 405 & & 10,655 & \\
Lightning & 184 & 124 & 308 & & 74,597 & \\
Total & 206 & $\mathbf{5 0 7}$ & $\mathbf{7 1 3}$ & $\mathbf{3 9 5 , 1 6 9}$ & $\mathbf{8 5 , 2 5 2}$ & $\mathbf{4 8 0 , 4 2 1 *}$
\end{tabular}

*No AFS acreages for human, lightning-caused fires; Number of fires in1986 Statistics (713) differ from figure in Summary for Calendar Years (396).

\section{Aircraft}

Passengers Hauled

Cargo Hauled

Hours Flown

$\underline{\text { Paracargo }}$

194,492 lbs.

$\underline{\text { Retardant }}$

742,675 gal.

EFF Pavroll

Gross Wages: $\$ 2,832,230.74$ No. Hires: 1,458

Assistance Dispatched to Lower 48

Personnel: 620 Aircraft: 1

Assistance Dispatched from Lower 48

Personnel: 717 Aircraft: 9

\section{Special Projects}

\section{Fire Familiarization Program}

1986 was the trial year for the Fire Familiarization Program. Ten individuals from the BLM Fairbanks District, Anchorage District and Alaska State Office were given the opportunity to gain fire experience and knowledge through an organized detail to the Alaska Fire Service. They were given basic fire training courses in the spring. For a two-week period in June, they were assigned to various AFS functions within the Zone organizations and Fairbanks. Their training and detail was coordinated by the Branch of Fire Specialists within the Division of Attack Systems. The FFP members gained experience in a variety of fire jobs: firefighter, helispot manager, supply worker, detection, radio operator, and administrative assistant. The program served to increase the list of qualified BLM employees available in the state for fire assignments. 


\section{Electronic Systems}

The Alaska Initial Attack Management System underwent considerable improvement for the 1986 fire season. The MV-8000 computer in Fairbanks was brought on line. It served as the hub to which the DG-20 field units were networked. Improvements made in the system included the ability to obtain protection information while in the lightning display mode, ability to look at the last four days' lightning displays, access to RAWS data for up to four days, access to BEHAVE (a fire behavior prediction system), and a newly developed program to transmit resource orders between offices. In addition, a mail system was made available, an automated version of BEHAVE was developed that accesses vegetative types directly from the fuels mapping information stored in the computer by latitude and longitude, and the Canadian Drought Index program was put on the computer. Lastly, the National Weather Service's fire weather forecasting was done directly on the MV-8000, and a connection was made between the Weather Service's ' PRIME computer system and the MV-8000, allowing easier access by both the AFS and NWS to fire weather information. Lightning and RAWS data are now archived on the MV- 8000 for review in the fall. Canadian lightning data, which includes positive and negative strikes, is also archived. A review of fire starts vs. the polarity of the lightning causing them needs to be done.

The Automated Lightning Detection System remained the same as it did during the 1985 fire season. Plans are being made to place a direction finder in Nome to detect lightning strikes that have been reported, but not detected by ALDS, on the Seward Peninsula.

Probeye use increased this year from last year due to the increased fire activity. A training course covering the operation of probeyes is scheduled for April 1987. This should help reduce the damage that occurs occasionally during field use. The U.S. Forest Service has a hand-held thermal I.R. sensor that was available this summer. A study needs to be done to compare the two. 
Alaska Fire Service

\section{6}

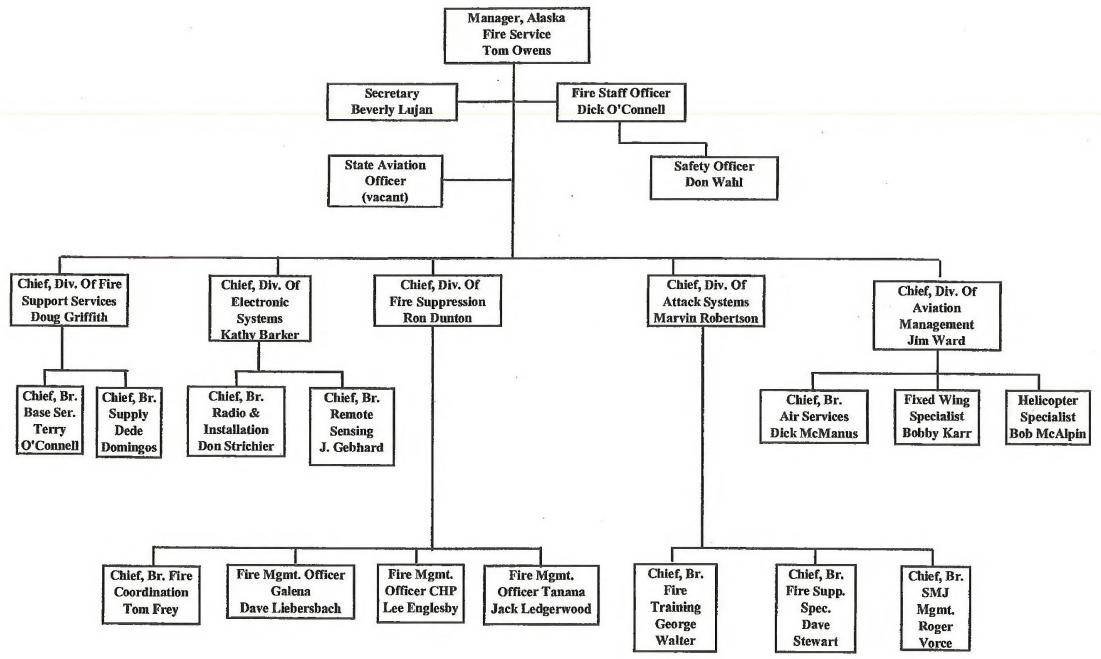




\section{Season Highlights}

The major highlights of the 1987 fire season were the increasing cooperation between the various agencies involved in wildfire suppression activities in Alaska, as well as the increased inter-regional cooperation with the lower 48 states. The Alaska fire season did not turn out to be as severe as expected.

During the spring and early summer it appeared that Alaska was headed toward a major fire year. The snow pack throughout much of the state was below normal, the temperatures were higher, and April and May precipitation was significantly lower than normal. Although, in terms of fuel moisture and general burning conditions, high potential for fire starts continued throughout much of the summer, lightning activity never developed to the degree necessary to cause a major fire problem. On June 24, 22 new lightning fires were reported across AFS protection areas, and July 14, 30 new fires were reported. These two lightning busts did not cause any significant problems.

Two large fires, both burning on military lands, accounted for the largest commitment of firefighting forces during the season. The Granite Creek fire, which started on May 22 near Fort Greely, spread 12 miles on the day of discovery and threatened Delta Junction by the evening of the first burning period. A maximum of 650 people staffed the 43,500-acre fire, which was contained on May 28 with no structures lost or major injuries. The second large fire started on Eielson Air Force Base on June 23. On July 5, the fire made a major run, growing from 890 acres to an estimated 2,600 acres and producing a tower of smoke which caused concern among local residents. The 10,960-acre fire was contained July 9 by 690 firefighters. The total cost of fighting these two fires was around $\$ 5.6$ million.

1987 was the first year of operation for the Alaska Interagency Fire Coordination Center, which combined the operations of the State of Alaska's Central Office Logistics with the Alaska Fire Service's Fire Coordination Center. The cooperation proved to be very effective. Statewide initial attack coordination was handled by the AFS dispatchers, logistics was a joint operation, and a single statewide situation report was produced daily.

On Aug. 31, the Boise Interagency Fire Center began ordering manpower from AFS for what was to become the largest commitment of Alaskan firefighters to the lower 48 states since there has been an organized suppression organization in Alaska. More than 1,600 personnel were sent from Alaska, including 65 Type II crews, 15 helicopter modules, 24 dispatchers, and 18 smokejumpers. Of the overhead sent down, AFS filled 187 positions, the State of Alaska 115 positions, and the U.S. Forest Service 23 positions. In addition, the USFS sent 116 people to fill out six of the Type II crews. In addition, the AFS warehouse shipped 150,000 pounds of equipment and supplies to support the fire-fighting efforts.

Another example of interagency cooperation was the detail of the Mendocino Hotshot Crew from Region 5 of the USFS to Alaska, from June 8 to July17, and the reciprocal detail of the Chena Hotshot Crew from Alaska to the Mendocino National Forest on July 29.

On Oct. 22, a fire burned one of the AFS warehouse cold storage buildings to the ground. About $\$ 2$ million worth of fire stores and other gear was destroyed. 
1987 Fire Statistics - Statewide

\begin{tabular}{lccrr} 
Cause & \multicolumn{2}{c}{ Number of Fires } & \multicolumn{2}{c}{ Acres } \\
\cline { 2 - 5 } \cline { 3 - 5 } & AFS & State & AFS & State \\
Human & & 453 & & 5,848 \\
Lightning & & 36 & & 7,303 \\
Total & $264^{*}$ & 489 & 166,796 & 13,151
\end{tabular}

*AFS totals include 80 fire numbers for fires in state protection zones. Those fires are probably also included in state totals, which are taken from the DOF 1987 Annual Report. AFS Statistics do not provide breakdown for human and lightning-caused fires.

Aircraft

Total Passengers Total Cargo

3,930

$415,250 \mathrm{lb}$.

Total Flights

975

Assistance Dispatched to Lower 48

Personnel: 1,613

Assistance Received from Lower 48

Personnel: 211

Paracargo

$116,940 \mathrm{lbs}$.

Retardant

603,255 gal.

EFF Payroll

Gross wages: $\$ 5,838,108.62$

\section{Special Projects}

The 1987 fire season was the first operational season for the North Star Fire Crew. The crew was organized to establish a larger entry level pool for AFS and to provide an additional hand crew for fire managers. While on project work, crew members volunteer their services. When assigned to a fire the crew members are paid EFF wages. The crew was available from June 1 until Aug. 14. During that time they were on fires 46 days and spent the rest of their time on project work and training. 


\section{AFS Organization}

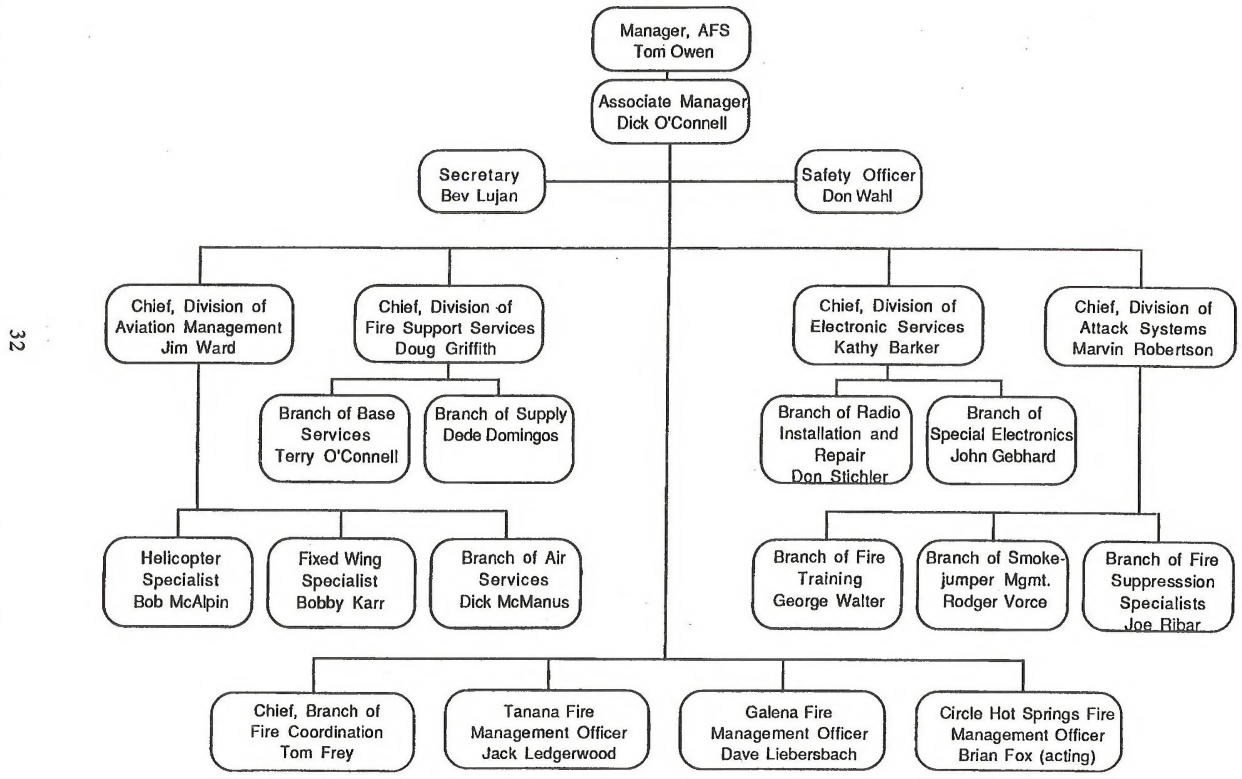




\section{Season Highlights}

The 1988 Alaska fire season was the most severe season in the past 10 years. More than 2.1 million acres were burned statewide. The Alaska Fire Service mounted a massive mobilization effort during July and August to suppress the fires. The effort included the support of Alaska's interagency suppression community as well as substantial support from the Lower 48.

The season began with a fire that started on April 14 on the Fort Wainwright Army active artillery range. On May 10 the fire burned into fuels outside of the active range and increased in size to 13,780 acres. Smokejumpers were dispatched to try to stop the spread but were hampered primarily by the probability of fire ordnance still on the ground within the range. Successful burnout operations and a change in the weather kept the fire from burning several cabins.

A controlled burn on the Kenai National Wildlife Refuge, which burned out of prescription on May 26, was the cause of the next major mobilization of forces. A Class II overhead team was in place on the fire by the afternoon of May 27. On May 29 the fire received considerable rainfall, which resulted in total demobilization and the return of the fire to the Fish and Wildlife Service.

The first significant lightning activity began June 11, igniting 10 fires across the Upper Yukon and Tanana Zones. Lightning activity continued until June 17, and accounted for 90 new fires in six days. Most of these were in limited action areas, although enough were in modified and full suppression areas to cause the mobilization of additional smokejumpers and the Lassen Hotshot. crew from the Lower 48 . With the additional forces and the help of some timely rain showers, none of the new fires gained enough momentum to become problem fires.

Many of the limited action fires continued to burn into July. Low relative humidities, frequently in the low 20 s across the state, and unusually windy conditions (10-20 mph surface winds) throughout the month of July, caused many of the limited fires to increase rapidly in size. Some fires were increasing by as much as 10,000 acres per day. This increased activity generated a large volume of smoke, which began to fill the large shallow basins of Interior Alaska. The Multi-Agency Coordination Group met to re-evaluate the fire management options provided for in the Alaska Interagency Fire Plan. The decision was reached to continue with the Modified Suppression option rather than converting to the Limited Suppression option on July 10, and to allow fire management officers the option to take action on limited fires in certain areas. At about the same time, the Galena Zone became very active with new starts near Huslia and Hughes as well as an increasing commitment to a fire near Selawik.

A total of nine aircraft, 792 people, and extra supplies and equipment were ordered from the Lower 48 to support the AFS suppression effort. Ten fires received Class II team management during July. At the end of July, four Class II teams with approximately 50 crews were still being supported along with several multi-crew Class III fires.

By mid-August, fire activity began to wind down in Alaska. Moist weather patterns had slowed the fires. Fire managers had achieved their suppression objectives, which in some cases were to protect cabins and in others containment and control of the fires.

The final period of fire activity for AFS began with the mobilization of crews, overhead, equipment and aircraft to the Lower 48 to help with suppression efforts, primarily in Montana. In 
a combined effort of state and federal agencies, 1,550 firefighters, including 63 crews, 14 aircraft, and thousands of pounds of equipment and supplies were mobilized and sent south.

Alaska's last firefighter returned from assignment on Nov. 23, ending what had been a long, record-setting season. More paracargo was dropped, more people were on fires in Interior Alaska, and more support was received from the Lower 48 than in any previous fire season.

\section{Fire Statistics - Statewide}

\begin{tabular}{lcr} 
& Number of Fires & Acres \\
\cline { 2 - 3 } & 347 & 20,982 \\
Lightning & 255 & $2,113,660$ \\
Total & 602 & $2,134,642$
\end{tabular}

Aircraft

Total flights Total Passengers Total Cargo Flight hours

$2,180 \quad 11,215 \quad 7,133,072$ lbs. 15,600

Assistance Dispatched to Lower 48

Personnel: 1,550 Aircraft:14

Assistance Dispatched from the Lower 48

Personnel: 792 Aircraft: 9

Retardant

$851,755 \mathrm{lbs}$.

Paracargo

$1,552,360 \mathrm{lbs}$.

EFF Payroll

Gross wages: \$9,620,968.28 Hours worked: 886,903 


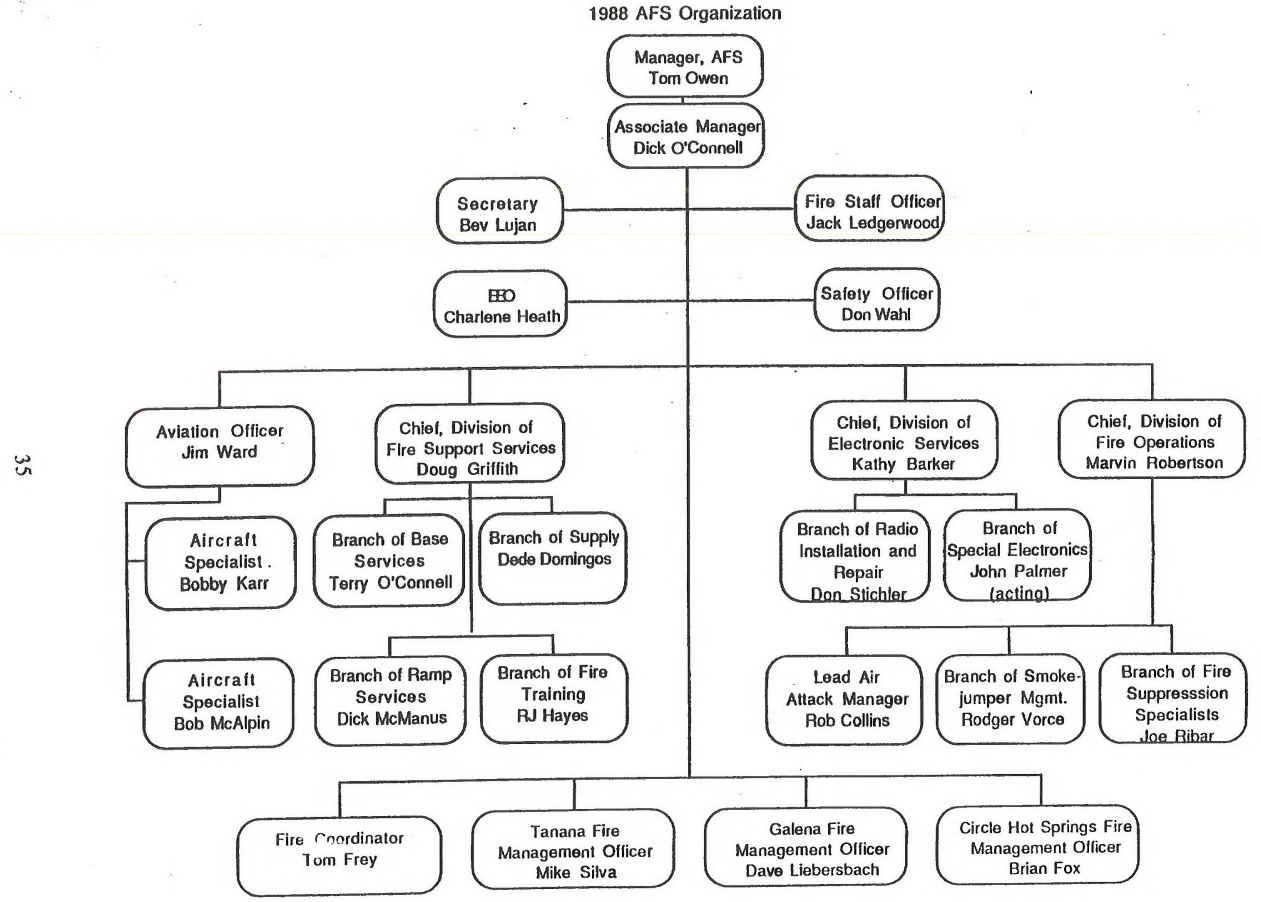




\section{Season Highlights}

The 1989 fire season in Alaska was very different from the 1988 season when, statewide, 602 fires burned 2,134,642 acres. Of those fires, 259 were in Alaska Fire Service protection zones and burned 2,003,442 acres. In contrast, this year AFS issued 149 fire numbers, of which only 68 were for fires or false alarms in AFS protection zones. Eight of these were false alarms, one was for a 9,000-acre fire that Canada asked AFS to fight, and the remaining 59 AFS protection fires burned only 1,825.2 acres. The other 81 numbers were issued for support for State of Alaska or U.S. Forest Service protection fires in Southeast Alaska, for which we provided a Class III and a Class II team, as well as two hotshot crews.

The main effort of AFS this year was in support of other agencies, rather than in fighting its own fires. AFS supplied major support effort for the Prince William Sound oil spill containment effort, the fire bust in the McGrath area protected by the State of Alaska's Southwest Area Forestry, the U.S. Forest Service Region 10 on Prince of Wales Island in the Ketchikan Area of the Tongass National Forest, the Canadian Yukon Territories Northern Affairs Program, Forest Resources, and to the Lower 48, where we sent 61 Type II crews, 54 of which were EFF crews.

The Alaska Class I team was used on assignments to the Prince William Sound oil spill and to a fire in the Nez Perce National Forest in Idaho.

Tom Owen retired as the Manager of AFS in September, 1989.

\section{Fire Statistics - Statewide}

\begin{tabular}{lccc} 
& Number of Fires & & Acres Burned \\
\cline { 2 - 3 } Human & 440 & & 15,505 \\
Lightning & 45 & 53,388 \\
Total & 485 & 68,893
\end{tabular}

\section{Aircraft \\ Total flights Total Passengers Total cargo Flight hours $1,087 \quad 6,483 \quad 1,696,554 \quad 4,804$}

\section{Paracargo}

$124,800 \mathrm{lbs}$.

Retardant

175,738 gal.

Assistance Dispatched to Lower 48

Personnel: $1,526 \quad$ Aircraft: 12

Assistance Dispatched from the Lower 48

Personnel:131 


\section{EFF Payroll}

Gross wages: $\$ 4,078,744.06$ Hours worked: $364,043.4$

\section{Oil Spill Assistance}

AFS provided assistance to the clean-up efforts of the Prince William Sound oil spill. The Alaska Class I overhead team was sent first to Valdez and then to Seward to manage the National Park Service effort in mobilizing for the protection of the Kenai Fjords National Park. As the oil spread south and west toward Kodiak Island, the National Park Service effort expanded to include Katmai National Park. The U.S. Fish and Wildlife Service ordered a Class II team from AFS to help with their efforts on the Kodiak and Becharof National Wildlife Refuges. In addition, both teams provided assistance to the Kenai Borough. 


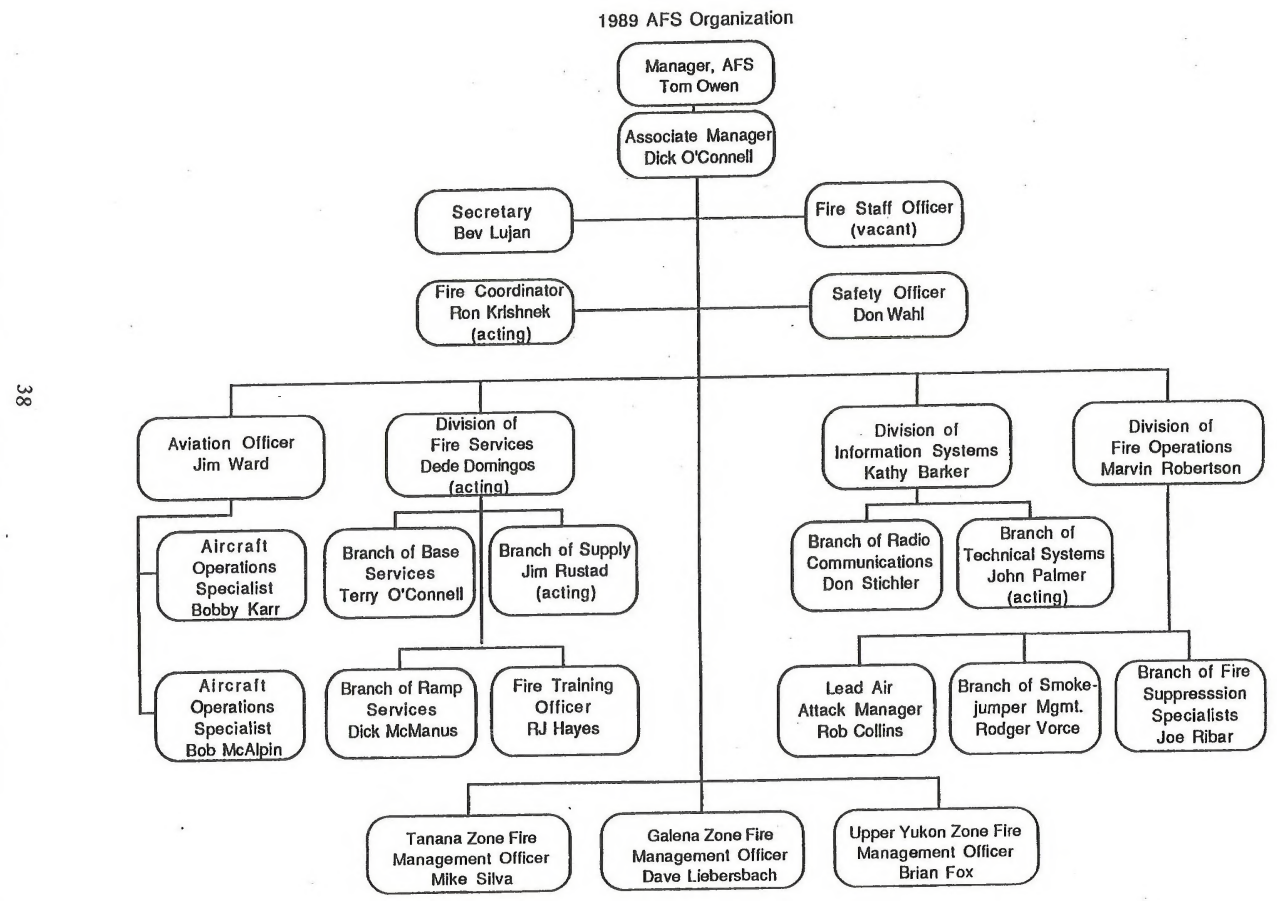




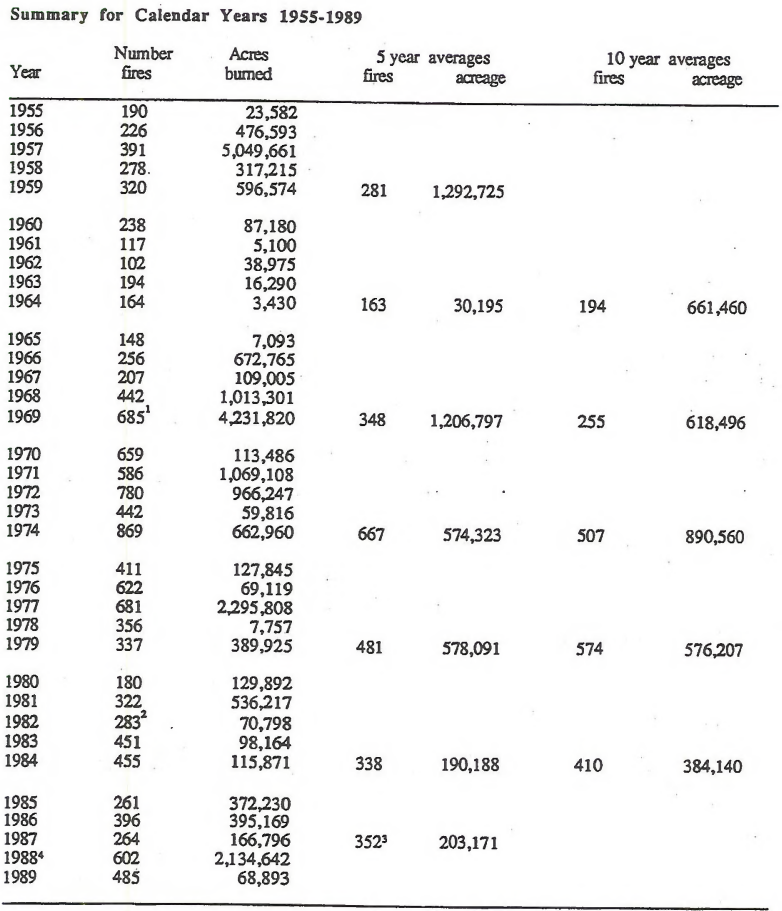

${ }^{1}$ Total fire numbers from 1969 on includes false alarms.

IIn 1982 the State of Alaska assumed protection responsibilities for its own lands. The number of fires listed above from 1982 to 1987 does not indicate the total number of fires that occurred in Alaska, nor the total acreage burned.

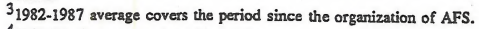

${ }^{4} 1988-89$ figures are statewide totals. 


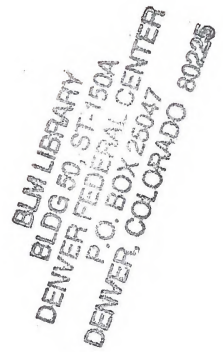


